\title{
MEDIA CONTENT ANALYSIS IN THE PROVINCE OF EAST KALIMANTAN AND PUBLIC PERCEPTION ON THE IMPLEMENTATION CORPORATE SOCIAL RESPONSIBILITY
}

\author{
Rina Juwita \\ Prodi Ilmu Komunikasi FISIP Universitas Mulawarman \\ Email: rinajuwita1704@gmail.com
}

\begin{abstract}
ABSTRACK The issue of Corporate Social Responsibility is considered as a sensitive issue since it relates to the company' contribution to develop and to increase community welfare. However, the concept of CSR implemented by the corporations is more on carring the image building and social investment mission made by the public relations division through the mass media. Therefore, this media content analysis is conducted to determine the CSR trend reported by the corporate and the media. The analysis was done quantitatively which are presented in tables and charts, then riched with interviews to refine the analysis. Based on the research, the CSR news covered is more on the charity/donor/sponsorship, and frequently used as a tool of corporate PR to promote 'the good things' that have been undertaken by the companies. The public representative also stated that the CSR news written by the media more on to promote that the company has done good things for the community. This happens because of the news only contain info and photos that show the sheer relief only which indicate that the newspaper has a firm economic independency that creates a situation where the media cannot be actively critic the CSR programs which have undertaken by the companies.
\end{abstract}

Keywords: Content Analysis, CSR Implementation, Public Perception

\section{ANALISIS ISI MEDIA DI PROVINSI KALIMANTAN TIMUR DAN PERSEPSI PUBLIK TERHADAP IMPLEMENTASI TANGGUNG JAWAB SOSIAL PERUSAHAAN}

\begin{abstract}
ABSTRAK Isu Tanggung Jawab Sosial Perusahaan (CSR) merupakan sebuah masalah yang dianggap sensitif karena berkaitan dengan kontribusi yang diberikan oleh perusahaan baik itu nasional dan multinasional untuk mengembangkan dan membantu meningkatkan kesejahteraan masyarakat. Namun demikian, konsep CSR yang diimplementasikan oleh perusahan-perusahaan tersebut lebih untuk membangun image dan misi investasi sosial yang dibuat oleh divisi Humas melalui media masa. Oleh sebab itu, analisis isi media ini dilakukan untuk menganalisis kecenderungan pemberitaan tentang CSR yang dilakukan oleh perusahaan dan media. Analisa dilakukan dengan pendekatan kuantitatif yang disajikan dalam tabel dan grafik, kemudian dilengkapi dengan data interview untuk memperoleh data yang lebih komprehensif. Berdasarkan penelitian, berita CSR yang dimuat lebih banyak tentang amal/ donor/sponsor, dan sering kali digunakan sebagai alat humas perusahaan untuk mempromosikan 'hal baik' yang dilakukan oleh perusahaan. Persepsi publik yang didapatkan juga menyatakan bahwa berita CSR yang dimuat oleh berita lebih untuk mempromosikan perusahaan yang telah melakukan hal baik bagi masyarakat. Hal ini dilakukan karena berita-berita tersebut banyak memuat informasi dan foto yang menunjukan informasi positif semata yang mengindikasikan bahwa suratkabar memiliki ketergatungan politik yang menjadikan media tidak bisa secara aktif mengkritisi program CSR yang dilakukan oleh perusahaan.
\end{abstract}

Kata Kunci: Analisis Isi, Implementasi CSR, Persepsi Publik

\section{INTRODUCTION}

Corporate Social Responsibility (CSR) is an important concept and a medium for companies when responding to various matters that arise as a result of business or activities they $\mathrm{do}^{1}$. Corporate and its Public Relations Officer (PRO) try to respond the criticism addressed to them when they got labeled as company that does not care

1 Rampton, S. (2004), Corporate Social Responsibility and the crisis of globalization, Center for Media and Democracy. Available in http://www.prwatch.org/node/273/print about the social environment, by sending a message to the wider world that they do positively contribute to society in many ways, both in local and global scale (Prabu, Kline \& Dai, 2005).

Broadly say, CSR is defined as a corporate responsibility to the communities in which the company lies and operates. Specifically, CSR is a set of activities concerned on how company identifies and incorporates the needs and values of its 
public-public organizations in the decisionmaking process and then practicing them in day-to-day operation. That is why CSR is defined as a business commitment that the company made to act ethically and to contribute to economic development of the communities around its operations, as well as to improve the lives of the community beyond what has been expected by the law. Companies actually should conduct a voluntary CSR and then accommodate the attitudes and actions and not merely thinking about profit, which further helps to improve the quality of life of communities and individuals who live in the area around the company' site for the persistence of both the community and the company (Jamilah \& Ngurah , 2010).

The concept of CSR in the current time has been identified as a global demand, in which CSR is not merely a voluntary action for a corporation but more to the extend of practical approach to identify business ethic for an organization (Nejati \& Amran, 2009), particularly (but not limited) for a corporate, whether it is a small or a big company, local or international. CSR has been created when the government, consumer, employees, supplier, and community groups start to oblige the company to act responsibly in their operational basis (Bondy, Moon \& Matten, 2012). The optimism is then made to integrate corporate social, environmental, and economic responsibility challenges they have in each of their operations (Gariga \& Mele', 2004; Norman \& McDonald, 2004), so that the company could obtain social support as well as achieving their economic goals.

In Indonesia, there are some regulations that were passed by the government to initiate the concept of CSR. First is the Act No. 25 of 2007 on Investment which states that 'every investor shall implement corporate responsibility'. Then there is the Law No. 40 of 2007 on Limited Liability Article 74 paragraph 1 states that 'the company conducting its business activities in the field and/or related to the natural resources required to fulfill its social responsibility and the environment management', which is then amplified in the second paragraph which states that as the concrete form of CSR obligations, the company must include CSR funds in the company financial plan and it should be calculated as the cost. After that, there is Government Regulation No. 47 year 2012 which strengthens the mandatory concept of CSR.

However, at this time, the CSR held by corporations more onto the mission of image building and social investment made by the public relations division. The implementation of CSR is often only as a strategy to gain public legitimacy to be labeled as good corporate governance, so then it is no longer defined as a true public relations works. Though the concept of PR and CSR actually not only possess the community relations and community services, but emphasizing on community empowerment.

It really is an ironic since it is undeniable that the corporate activities, the plant operational, or the facilities frequently impact directly or indirectly to the environment in which they operate (Rondinelli \& Berry, 2000). Therefore, it is a fact that the problems occur in community often come from the company's operations due to negative impacts result from its activities. So then the company should do more than just repair the impact which arise from their operation (Kusku, 2007).

At the time the media reports the issues and events that occur in the community, it actually can be said that the media has run its function and role to inform the social life phenomenon. At this point it subsequently becomes the right of public to respond and to assess of what is happening in their lives, what influences them and what does not. The media presence then plays an important role not only for society but also for the government, as well as corporation as an economic actor. One of the essential elements of the media in this process of sustainable development is the availability of information to the public on what is happening in the environment around them.

Recently, many scholars discover the increasingly phenomenon that obscure the CSR meaning and concepts in its implementation. The chairman of Indonesian Consumers Foundation (YLKI) Tulus Abadi 
stated that the concept of CSR in practice is often performed as a hidden campaign ${ }^{2}$. The CSR programs are carried out frequently just to increase the company market share of the products marketed ${ }^{3}$. Otherwise it just to show the public that the company has given something back to the community, which in reality what they gave nominally just a small part of the PR budget to merely fulfill their obligation. Such situation is not something that is 'beyond the compliance' as the basic concept of CSR should be.

Indonesia itself has been committed to seriously implement the concept of sustainable development which one of them is by maximizing the CSR programs. However, of the dozens of national and international companies operating in East Kalimantan, it was never able to obtain the exact figure how many are used for CSR activities themselves (hukumonline.com, 2012). Even according to Zain Taufik Nurrohman (member of East Kalimantan Parliament), there are still many companies that are not truthful about their CSR activities and how it used to.

Media presence then becomes very important not only for society but also for the government and the corporation as the economic actor to disclose such information. Since one of the essential elements of media in the process of sustainable development is to provide information which is open to the public on what is happening in the environment surround them.

Based on the situation that has been discussed above, the research issue covers some questions: 1) How large is the proportion of CSR reports in in Kaltim Post and Tribune Kaltim as the two largest printing media in East Kalimantan? 2) What theme is written in the news about the CSR in those two media? 3) What kind of pictures displayed on the issue of CSR? 4) Who is the source of CSR news published in the media? And 5) Does the CSR news that was published in Kaltim Post and Tribune Kaltim have been had positive impact on public perception?

2 Republika Online (2011), Indonesia Salah Kaprah Ter jemahkan CSR. Senin 03 Oktober 2011.

3 Pratika, A), 'Promosi Rokok di Balik Kedok CSR', Lipu tan6.com, 28 Mei 2012.

\section{METHODOLOGY}

This content analysis of mass media coverage on Corporate Social Responsibility and its implications for public perception in the province of East Kalimantan is conducted quantitatively and then riched with some qualitative data. The news subjected in this research is those that have been published about CSR, written in Kaltim Post and Tribun Kaltim in the period of November $6^{\text {th }}-$ December $5^{\text {th }} 2012$. Some depth interviews are held with the Corporate Forum for Corporate Development in East Kalimantan, Public Relations Association Chapter Samarinda, and 10 Communication studies students in University Mulawarman.

\section{RESULT AND DISCUSSION}

There are many definitions on CSR proposed by scholars around the world. However, there is one of the most frequently cited definition by Carroll (1979) that defined CSR as the social responsibility of a business activity that includes the economic, legal, ethical, and philanthropic in the community in which the organization operating at a particular time and geographic location. Whelten, Rands and Godfrey (2001) regard CSR as a social responsibility to the community or the moral obligation own of every business unit.

Joyner, Payne and Raiborn (2002) categorize CSR as economic and laws activities relate to corporate ethics and wisdom that are tailored to community values and expectations. According to them, CSR is the basic expectation of a company as a form of initiatives taken to improve public health, public safety, and protecting or preserving the environment from the operating activities as well as the impact caused. In this context, they explained that social responsibility is influenced by the given social reality, culture, norms and standards of the place where the company operates. The CSR implementation undertaken by each company depends on the mission, culture, environment and profit, as well as companies operating conditions (Susiloadi, 2008). 
Meanwhile, people's views or opinions on a company's image and reputation are owned and acquired through advertising, news, and information available in the media (Fombrun \& Shanley, 1990). This is caused by the news selectively reported by the media (Shoemaker et al, 2001) or the author of the news at a given time; caused by the limitations of time and place, there is always an excess story presented in the community than media able to publish (Carroll \& McCombs, 2003). Therefore, it is impossible to bring out all the news about CSR undertaken by the company in the media, at a particular time and place. However, companies typically use a range of strategies such as creating press releases to increase the chance that their CSR activities will be reported in the media, with the intention that the media can convey the desired message to the subjected target by the company (Shoemaker et al, 2001).

According to the CSR Digest ${ }^{4}$, CSR and media go hand in hand where the media disseminate the CSR information to the public. Media reports on CSR is often illustrate the companies philanthropic; such as giving to the poor, sponsoring educational and charitable activities that can be useful for those who are less fortunate, and so forth.

However, some argue that there should be standards set forth in the media, so the CSR can be reported as it should be. It then could be the means by which the media can disseminate accurate information on behalf of the public in order to create good governance by government institutions, companies, NGOs and others. The media should also be able to play its role as a watchdog to criticize the organization that uses CSR as media to acquire free publicity for the organization. CSR reports on media actually should emphasize the CSR initiatives which require long-term attachment to sustain both the organization

4 CSR Digest (2009), Media and CSR (Online), http://www. csrdigest.com/2009/04/media-and/csr and the community development. However, some argue that this responsibility has been traditionally entrusted to media so the media role is not bothered by subsidising media when reporting CSR activities of the company

\section{Content analysis on CSR Reports in Kaltim Post and Tribun Kaltim}

This content analysis on CSR Reports was taken on the period of $6^{\text {th }}$ November$5^{\text {th }}$ December 2012. The data was collected purposively with a total of 30 editions consists of 68 pieces of news. During this period, Kaltim Post was published about 41 posts $(60 \%)$ and Tribune Kaltim posted about 27 pieces (40\%) of CSR news. Below is the figure that shows the number of stories published by both newspapers.

\section{Figure 1}

Number of CSR News Pource: Processed data

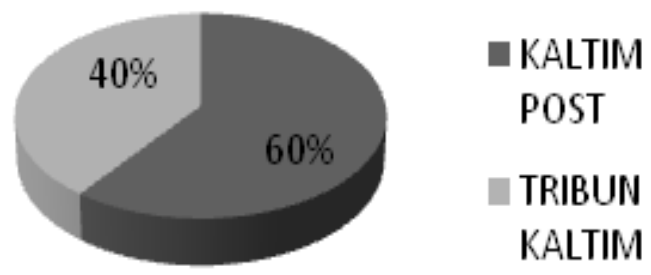

news in $<25-50 \mathrm{~cm} /$ column. It indicates that both newspapers prefer to publish CSR news in such a brief and fleeting piece. In the figure also appeared that there is no news packed in more of $50.1 \mathrm{~cm}$ in size.

Figure 2

CSR Reports Distribution Based on the Size Column

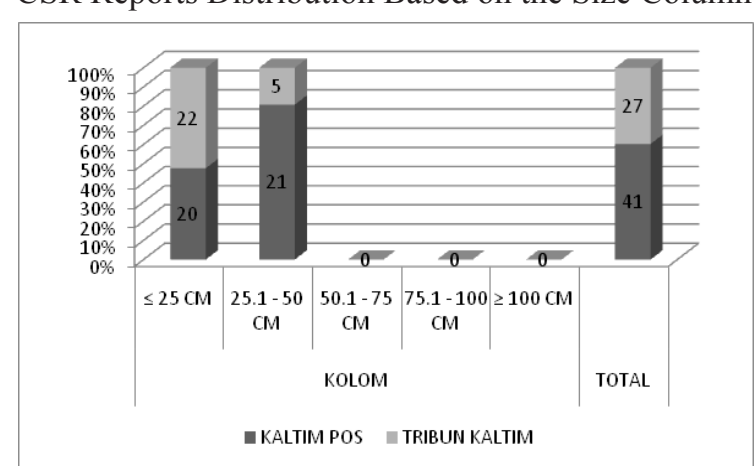

Source: Processed data

Thus it can be said that these two newspapers were not presented enough detail on CSR news. It is said so because news written in such little column are usually 
stories that only have a short, concise, and just a glimpse of material, which are the types of spot news and hard news (Santana, 2004). Such news was clearly not enough to describe what has actually been implemented by the company and whether it was really a CSR activity or just to fulfill their obligations institutionally. Therefore, according to Downie and Kaiser, the media in this case can be said as doing a bad journalism, where the media proclaim an event only at its surface and not comprehensively reported (Santana, 2005). Such incomplete information will only deceive the public about the company contribution and participation.

Figure 3

CSR Reports Distribution Based on Rubric

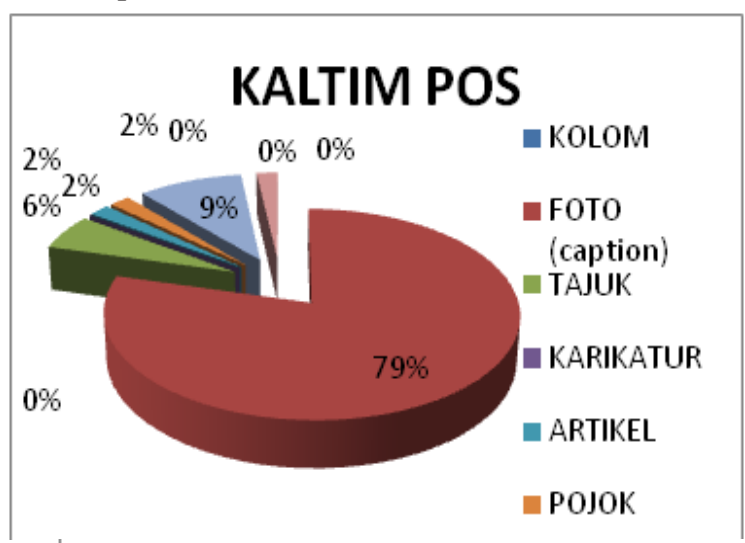

TRIBUN KALTIM

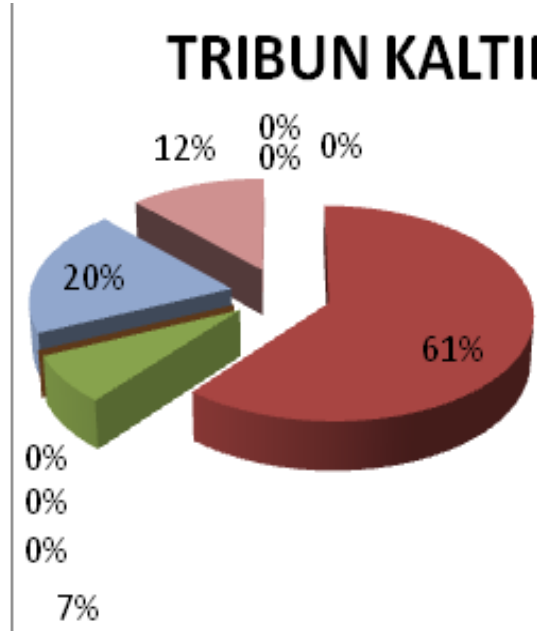

Source: Processed data

From the news presented, both newspapers tend to use photos and advertorials in publishing the CSR events. It indicates that CSR news more on to emotionally and evocatively made to convince the readers that the company has done something beneficial for the public welfare. Some were also been presented in the form of advertisement that is more likely to promote what is carried or to be merketed by the company.

Moreover, the CSR reports on Kaltim Post and Tribun Kaltim were dominated by straight news reporting format. There were just a few CSR news packaged in comprehensive and in-depth news with depth techniques and it was done merely by Kaltim Post. This illustrates that the Kaltim Post and Tribune Kaltim tend to write factual events but less explores on the complexity of the implemented CSR comprehensively.

Moreover, the figure below shows that the sources most frequently referred in writing the news were dominated by the company representative, which in this case is the company that carried out the CSR activities. Although in Kaltim Post the primary sources was journalists $(51 \%)$ themselves, but the second percentage was the company representative which reach about 39\%, while at Tribun Kaltim it reaches about $67 \%$.

\section{Figure 4}

CSR Reports Distribution Based On News Sources

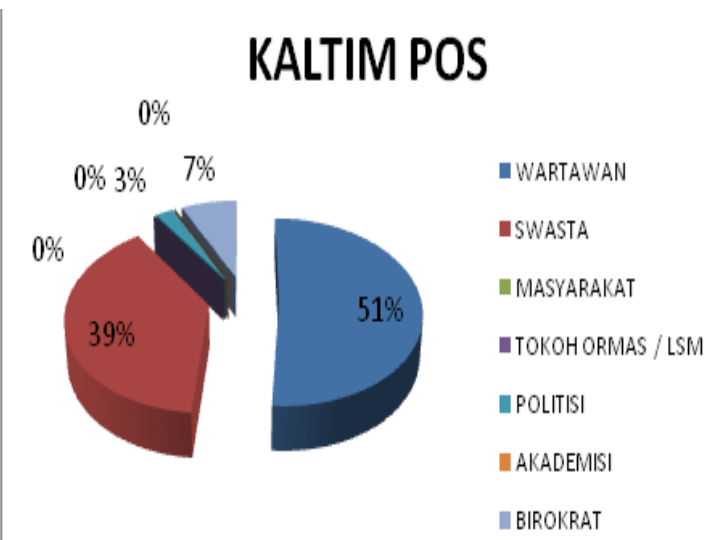

\section{TRIBUN KALTIM}

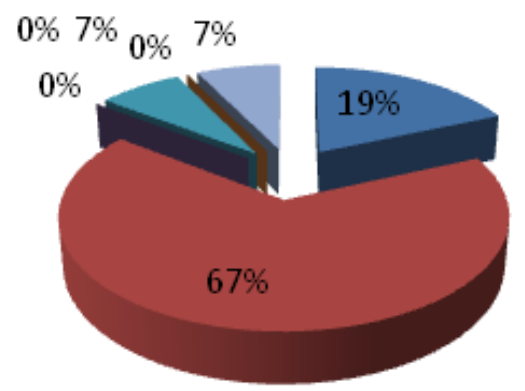

Source: Processed data 
The fact demonstrates that the company is still the major sources of the CSR reports, and those are usually the release issued by the Public Relations officer or equivalent. Such well-written news released by the company defined as 'information Subsidies' (Griffin \& Dunwoody, 1995; Zoch, 2006; Sweetser \& Brown, 2008). The media which repeatedly be given the information from the company and then used that in writing the news content are presumably will gradually lose its critical point on the reality happen in public life. Why is it so? Since such condition provides opportunity for the company to shape the media agenda as well as the public agenda. This situation further might reduce the news independency and objectivity which presented to the public. So the CSR reports are more as the company's efforts to get free media exposure for their promotional purposes only.

Figure 5

CSR Reports Distribution Based on News theme

\section{KALTIM POS}

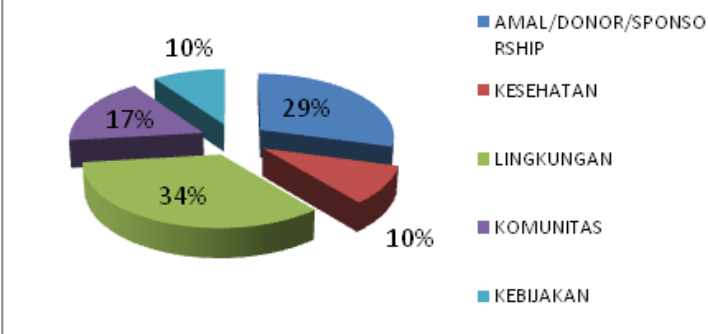

\section{TRIBUN KALTIM}

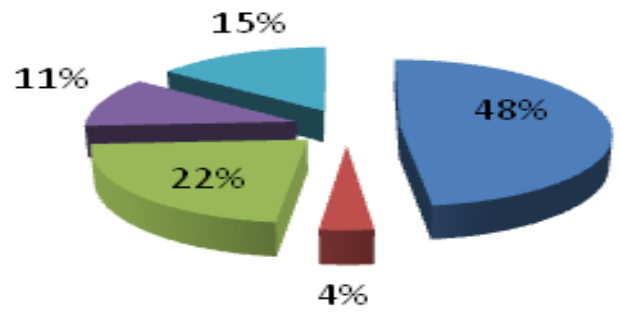

Source: Processed data

From the figure above it looks that the CSR news wih charity / donor / sponsorship theme were firstly dominate in Tribune Kaltim (48\%), followed by the environmental management issue (22\%). On the other hand, Kaltim Post published the CSR story on environment (34\%) in the first, and the second is for charity/donor/ sponsorship (29\%) news theme. In general, the reports on charity/donor/sponsorship shows as the most enjoyable read by the newspapers. Such reports usually about the scholarship distribution, the arts festival sponsorship, donation, building renovation, prize fund, and so on. Another way to gain public emotion to convince that company has done something good to empower community surrounding them.

\section{Public Perception Analysis On CSR News in Kaltim Post and Tribun Kaltim}

Public perception analysis on the implementation of CSR in the province of East Kalimantan was conducted through interviews with several informans who are considered as competent to the issue. The interviewees were The first chief of Corporate Forum for Community Development (CFCD) East Kalimantan, Public Relations Association (Perhumas) chapter Samarinda, and 10 students of Communication Studies at the University Mulawarman.

CSR is defined as the company's commitment to improve the community welfare by doing good business practices and by contributing the company's resources. According to Tedy Nawardin (CFCD), CSR itself is commonly defined as a continuous process of empowering communities so they can gradually boost their potentials (interviewed on $24^{\text {th }}$ November 2012). This is similar to what is presented by M. Faisal (Perhumas Samarinda):

"CSR is an effort to build a harmonious relationship between the company and the environment in broad sense; specifically as a commitment from the company to share or to make a real contribution to the internal or external environment, to improve the economy, public services and public welfare." (Interviewed on 22 $2^{\text {nd }}$ November 2012).

In the last few years, a growing number of CSR activities were carried out. Many large companies carried forward some programs on behalf of CSR and then race to boost the company reputation and their 'brand awareness'. According to M. Faisal, CSR should be implemented in a tangible 
form that directly perceived by the public as an effort to improve the public's living standard and to improve their lives quality economically, so public later know how to carry out their sustainable development (interviewed on 22 nd November 2012). Moreover Tedy Nawardin explained that:

"In applying CSR program, companies should really pay attention to the local characteristics, such as; cultural and natural potential, as well as the local wisdom. The company must also consider the relevance of CSR with the enterprise business processes, though it is not an absolute manner. It is because the community involvement will generate the public support and participation for the company's existence and live continuance shared by the community and the company.

In this recent times, there are many approach underlined the CSR practices, such as the MDGs or ISO 26000. However, essentially, the CSR programs must be processed through sharing ideas. There are three approaches in developing CSR programs. First, the program based on the company's program. Second, the program based on community proposition. Third, the proposed program of strategic partners such as local governments.".

Mass media is actually one of the public information sources which ideally should reports a critical publication on the occurred events. However, according to the CSR consultant, behind such obligations to be critical, some media wait for the CSR advertorial from these firms on behalf for their economic interests (RepublikaOnline, 2012). This situation resulted that the publication on CSR is merely promotion in its nature. It is in-line with Tedy Nawardin opinion who said that:

"The news media coverage on CSR is quite good in quantity but it is still less in the quality. It means that it is still not proportionale since it exposes more on ceremonial activities. "(interviewed on $24^{\text {th }}$ November 2012).

However, M. Faisal has a different view. He said that CSR news published by those two media is already good to notify public on company's participation to its environment, as long as it is not done for promotional purposes only. According to him, although there is for sure a hidden agenda as company propaganda to promote companies and its brand, but such activity might assist the company efficiency and effectiveness on budget so it can be used for other activities.

Communicating CSR surely will enhance the company's reputation in the eyes of the public as well as might improve the corporate's social value hedging because there would be more and more people are aware of the corporate social investment. In the long term, this matter may help to lower the company's risk due to the possibility of social unrest. Since it is known that without having such social hedging, it allows social upheaval that might negatively effect long term and requires much money. By having the CSR program, the company is already doing good saving starts from the financial side to the public trust.

Kelly, Graves and Waddock (2002) indicate that "the main purpose of corporate news releases are aimed at the media to provide society with an accurate understanding of corporate activities and to carry out one's responsibility to inform the public '. However, when the news released by the company-which is classified as' information Subsidies'- (Griffin \& Dunwoody, 1995; Zoch, 2006; Sweetser \& Brown, 2008) received from the company and then used by the media to write the news, it might invites companies to shape the media agenda and certainly public agenda. This is usually done to subsidize the reportation cost, so the company could have their event reported with less cost. The argument presented is that the company could carry on their business operation, which is an important thing by providing information about the organization to the public through mass media (with subsidy information). However, it also raise another question whether the media reliance will reduce the independence and objectivity of the news delivered to the broad public or not. So that the CSR programs frequently 
translate as the company's efforts to get free exposure in the media for their interest.

Meanwhile, according to most of the other informans, the CSR activities undertaken by the company have been able to contribute to the process of sustainable development in the community. This becomes significant because the government has limited development budget, eventhough on the other hand the public expectations on the success of the development and improvement of public services is also increasing.

However, there is an intriguing concept expressed by Tedy Nawardin in an interview on the $24 \mathrm{t}^{\mathrm{h}}$ November 2012.

"There are still differences between the company and the government in the context of development. The government put the company's CSR program to synergize with the government 'inability' on the development budget. The problem is, the government often caught as only concerned with physical development due to the assumption that if it is fulfilled so the non-physical development will follow. Meanwhile, the company did not want to be trapped on the jargon 'cow had the milk, but goat has the name'; so the company choose to focusoin non-physical development; such as scholarships, training, economic empowerment and others. Whereas the physical development still exists even only in helping the 'powerlessness' of government. So basically, this concept could be synergized if both sides understand each other position and believe that the development can be synergized with the company program through a coordinated pooling program and not just the pooling fund. "

Therefore the community development approach should be applied near to the concept of empowerment and sustainable development. The principles of good corporate governance became the basis in measuring the success of CSR programs. Since the CSR performed at this level is not just to do good and to look good, but to make good, to create good or improving the welfare of society.

\section{CONCLUSION}

The results show that the content of CSR reports in newspapers can be seen from the presentation of CSR rubric, news sources, news content and news themes. It can also be seen from the size of the column provided in the newspaper to present the CSR activities.

1) From dimensional layout for the presentation of the news it is found that Kaltim Post and Tribun Kaltim provide more CSR publication in the form of photos, followed by the rubric article. It is parallel to the column size which is most frequently posted in $50 \mathrm{~cm} /$ column. The columns are usually written for regular news that placed on small columns such as news articles.

2) On the technical aspects of writing, Kaltim Post and Tribun news Kaltim only fulfilled the $5 \mathrm{~W}+1 \mathrm{H}$ which indicates a lack of in-depth news writing, and merely tend to show the facts on the ground without being equipped with a comprehensive review.

3) According to news sources, Kaltim Post and Tribun Kaltim mostly use organisation representation which explains the relationship between the press and companies. Which is in searching and making news, both parties is not just one-sided relationship but always tradeoffs.

4) In the aspect of news themes, the CSR posts that often raised by Kaltim Post and Tribun news Kaltim are about charity/ donor/sponsorship, then followed by environmental issues and the community empowerment. Based on the substance, the news raised by both newspapers tends to bring about news stories that is regarded more on promotional and just as information to the public, that can be categorized as a means to 'market' in order to attract public attention. From some discussion above it can be explained that the Kaltim Post and Tribun Kaltim have their role fulfilled to inform about the organizational activities. However, such role is still not implemented optimally. It means 
that the news presented is only to be informed and to attract public sympathy. Whereas the news which wrote only to expresses the fact on how much is the assistance given by the company is less able to gather community participation on the social responsibility owned by the company.

5) According to the informants, the CSR news published by the newspaper is just to show that the company has been doing something good to look good. This was stated by the first chairman of CFCD, the chairman of Perhumas chapter Samarinda, and 10 students of Communication Studies in University of Mulawarman. It is understood that the relationship between the press and the company is classified as a symbiotic mutualism. On the one hand, the press has been carrying out its role to be informative. On the other hand the company also get benefit from the news to support their work as well as to gain external public trust, either from activity donation/charity/sponsorship, or environmental management, and community empowerment.

\section{RECOMMENDATION}

1. The increasing CSR news reported in various media requires the company to think about CSR holistically, so the impacts will not only for the companies but truly for the community. Therefore, the implementation of CSR should be carefully planned in every enterprise agenda by involving the community

2. Journalists need to meet a set of rules that must be considered. For example; transparency and openness, human rights, the environment, consumers ethical, and legal company obligations as well as voluntary activities.

3. Media should be courageous enough to write on the negative aspects arised from CSR activity or to be critic on CSR activities and actual implementation as a support form for the community

\section{ACKNOWLEDGEMENTS}

The research was conducted by a team of researchers from the Faculty of Social and Political Science, Mulawarman University with the title of "Media Content Analysis In The Province Of East Kalimantan And Public Perception On The Implementation Corporate Social Responsibility ". The research was performed based on a selfmanaged Assignment Implementation Research Activities on the fiscal year 2012, Mulawarman University for the period for 2 months. In this opportunity we would like to thank for related parties; which are Mulawarman University Research Chair, Professor. DR. Makrina Tindangen, M. Pd, Dean of Social dan Political Science Faculty Prof. DR. H. Adam Idris, Chair of the Communication Studies Drs. Sugandi, M. Si. Lastly, all parties that eagerly assisted during the research process undertaken.

\section{REFERENCES}

Bondy, K., Moon, J. \& Matten, D. (2012), 'An Institution of Corporate Social Responsibility (CSR) in MultiNational Corporations (MNCs): Form and Implications, Journal of Business Ethics, Vol. 53 (1), hal. 100-116

Carroll, A. (1979), 'A Three-dimensional model of Corporate Performance, Academy of Management Review, Vol. 4, hal. 497-505.

Carroll, C. \& McCombs, M. (2003), 'Agenda-setting effects of business news on the public's image and opinions about major corporations, Corporate Reputation Review, Vol. 6 (1), hal. 36-46.

Fombrun, C. \& Shanley, M. (1990), 'What's in a name? Reputation building and corporate strategy', Academy of Management Journal, Vol. 33 (2), hal. 233-258.

Garriga, E. \& Mele', D. (2004), 'Corporate Social Responsibility Theories: Mapping the Territory', Journal of Business Ethics, Vol. 53 (1), hal. 51-71 
Griffin, R. \& Dunwoody, S. (1995), 'Impact of Information Subsidies and Community Structure on local press coverage of environmental contamination', Journalism and Mass Communication Quarterly, Vol. 72 (2), hal. 271-284.

Kelly, J., Graves, S. \& Waddock, S. (2002), '100 Best Corporate Citizens', Business Ethics, Vol. 11 (2), hal. 8-13.

Kusku, F. (2007), 'From Necessity to Responsibility: Evidence for Corporate Environmental Citizenship Activities from a Developing Country Perspective', Corporate Social Responsibility and Environmental Management, Vol. 14, hal. 57-72.

Jamilah, A. \& Ngurah (2010) 'CSR in Malaysia: The Practices and Perception. In Dealing with Corporate Social Responsibility in Malaysia and Indonesia', Aplikasi Corporate Social Responsibility (CSR) Perusahaan Malaysia dan Indonesia: Perspektif Komunikasi, Penerbit Fisipol UGM, Yogyakarta.

Joyner, B., Payne, D., \& Rainbom, C. (2002), 'Building Values, Business Ethics and Corporate Social Responsibility into the Developing Organisation, dalam Journal of Developmental Entrepreneurship, Vol. 7, hal. 113-131.

Nejati, M. \& Amran, A. (2009, 'Corporate Social Responsibility and SMEs: Exploratory study on Motivations fromm a Malaysian Perspective', Business Strategy Series, Vol. 10 (5), hal. 259-265.
Norman, W. \& MacDonald, C. (2004), 'Getting to the bottom of 'Triple Bottom Line', Business Ethics Quarterly, Vol. 14 (2), hal. 243-262.

Prabu, D., Kline, S. \& Dai, Y. (2005), 'Corporate social responsibility practices, corporate identity, and purchase intention: A dual-process model', Journal of Public Relations Research, Vol 17 (3), hal. 291-313.

Rondinelli, D.A., \& Berry, M.A. (2000), 'Environmental Citizenship in Multinational Corporations: Social Responsibility and Sustainable Development',European Management Journal, Vol. 18 (1), page 70-84.

Susiloadi, P. (2008), 'Implementasi Corporate Social Responsibility untuk Mendukung Pembangunan Berkelanjutan', Spirit Publik, Vol. 4 No. 2, hal. 123-130.

Sweetser, K. \& Brown, C. (2008), 'Information subsidies and agendabuilding during the Israel-Lebanon crisis', Public Relations Review, hal. 34, hal. 359-366.

Whelten, D., Rands, G. \& Godfrey, P. (2001), 'What are the responsibilities of business to society?', Handbook of Strategy and Management, Sage, London.

Zoch, L. (2006), 'Building a theoretical model for media relations using framing, information subsidies and agenda-building', Public Relations Theory II, Lawrene Erlbaum Associates, Mahwah-New Jersey. 